\title{
Penegasan Politik Hukum Desentralisasi Asimetris dalam Rangka Menata Hubungan Pemerintah Pusat dengan Pemerintah Daerah di Indonesia
}

\author{
Kadek Cahya Susila Wibawa \\ Fakultas Hukum, Universitas Diponegoro \\ d3d3k81@gmail.com / kadekwibawa@lecturer.undip.ac.id
}

\begin{abstract}
The legal politics of Article 18, Article 18A, and Article 18B of the UUDNRI 1945 (Indonesian Constitution) is not strictly states that Indonesia adheres to the concept of asymmetric decentralization in the administration of local government. Until now, Indonesia does not yet have a grand design of asymmetric decentralization policy. The asymmetrical concept runs by itself without having its main design. Indonesia needs to affirm its asymmetrical decentralization policy to ensure the implementation of local government in accordance with the politic of law in the UUDNRI 1945. The establishment of a basic law on asymmetric decentralization is one way to emphasize that Indonesia adheres to asymmetric decentralization in the operation of central government relations with local governments. The construction of the act that is built remains in the spirit of decentralization rather than centralization, is carried out asymmetrically rather than symmetrically and remains within the framework of the United State of Republic of Indonesia. The act becomes the lex generelis of all laws relating to the broadest local autonomy and special autonomy.
\end{abstract}

Keywords: Asymmetric Decentralization, Local Government, Central Government, Autonomy.

\begin{abstract}
Abstrak
Politik hukum Pasal 18, Pasal 18A, dan Pasal 18B UUDNRI 1945 menyatakan secara tidak tegas bahwa Indonesia menganut konsep desentralisasi asimetris dalam penyelenggaraan pemerintahan daerah. Indonesia sampai saat ini belum memiliki grand design kebijakan desentralisasi asimetris. Konsep asimetris berjalan dengan sendirinya tanpa ada design utamanya. Indonesia perlu penegasan kebijakan desentralisasi asimetris untuk menjamin penyelenggaraan pemerintahan daerah sesuai politik hukum dalam UUDNRI 1945. Pembentukan undang-undang pokok mengenai desentralisasi asimetris merupakan salah satu cara untuk menegaskan bahwa Indonesia menganut desentralisasi asimetris dalam penyelenggaraan hubungan pemerintah pusat dengan pemerintah daerah. Konstruksi undang-undang yang dibangun tetap dengan semangat desentralisasi bukan sentralisasi, dijalankan secara asimetris bukan simetris dan tetap dalam bingkai Negara Kesatuan Republik Indonesia. Undang-undang tersebut menjadi lex generelis dari semua undangundang yang terkait dengan otonomi daerah seluas-luasnya, otonomi khusus, dan otonomi istimewa.
\end{abstract}

Kata kunci: Desentralisasi Asimetris, Pemerintah Daerah, Pemerintah Pusat, Otonomi. 


\section{A. Pendahuluan}

Amandemen Pasal 18 Undang-Undang Dasar Negara Republik Indonesia 1945 (UUDNRI 1945) yang terjadi pada tahun 2000 membawa perubahan yang sangat signifikan terhadap penyelenggaraan pemerintahan daerah di Indonesia. Politik hukum dalam Pasal 18 UUDNRI 1945 semangatnya menjadi sangat berbeda dengan nafas dalam Pasal 18 UUDNRI 1945 sebelum amandemen. Hal tersebut tidak dapat dipungkiri bahwa reformasi 1998, telah membawa perubahan yang sangat mendasar pada sistem ketatanegaraan di Indonesia. ${ }^{1}$

Perubahan politik hukum dalam Pasal 18 UUDNRI 1945 sebagai hasil amandemen berpengaruh terhadap perubahan politik hukum dalam peraturan perundang-undangan yang berada di bawahnya. Hal tersebut menunjukkan bahwa hukum merupakan suatu produk politik yang memandang hukum sebagai formalisasi atau kristalisasi dari kehendak konstelasi politik yang saling berinteraksi dan saling bersaing.

Secara struktur Pasal 18 UUD NRI 1945 sebelum amandemen terdiri atas satu pasal, yang pada intinya menyatakan: Pembagian daerah Indonesia atas daerah besar dan kecil, dengan bentuk susunan pemerintahannya ditetapkan dengan undang-undang, dengan memandang dan mengingati dasar permusyawaratan dalam sistem pemerintahan negara, dan hak-hak asal-usul dalam daerah-daerah yang bersifat istimewa. Pasal 18 UUDNRI 1945 pasca amandemen secara anatomi mengalami perkembangan menjadi tiga pasal, yaitu Pasal 18, Pasal 18A dan Pasal 18B. Adapun selengkapnya ketentuan Pasal 18 UUDNRI 1945 menyatakan :

(1) Negara Kesatuan Republik Indonesia dibagi atas daerah-daerah provinsi dan daerah provinsi itu dibagi atas kabupaten dan kota, yang tiap-tiap provinsi, kabupaten, dan kota itu mempunyai pemerintahan daerah, yang diatur dengan undang-undang.

(2) Pemerintahan daerah provinsi, daerah kabupaten, dan kota mengatur dan mengurus sendiri urusan pemerintahan menurut asas otonomi dan tugas pembantuan.

(3) Pemerintahan daerah provinsi, daerah kabupaten, dan kota memiliki Dewan Perwakilan Rakyat Daerah yang anggota-anggotanya dipilih melalui pemilihan umum.

\footnotetext{
${ }^{1}$ Kadek Cahya Susila Wibawa, "Urgensi Keterbukaan Informasi Dalam Pelayanan Publik Sebagai Upaya Mewujudkan Tata Kelola Pemerintahan Yang Baik”, Administrative Law \& Governance Journal, Vol. 2, No. 2, Juni 2019, hlm. 2.
} 
(4) Gubernur, Bupati, dan Walikota masing-masing sebagai kepala Pemerintah Daerah provinsi, kabupaten, dan kota dipilih secara demokratis.

(5) Pemerintahan daerah menjalankan otonomi seluas-luasnya, kecuali urusan pemerintahan yang oleh undang-undang ditentukan sebagai urusan Pemerintah pusat.

(6) Pemerintahan daerah berhak menetapkan peraturan daerah dan peraturanperaturan lain untuk melaksanakan otonomi dan tugas pembantuan.

(7) Susunan dan tata cara penyelenggaraan pemerintahan daerah diatur dalam undang-undang.

Selanjutnya ketentuan Pasal 18A UUDNRI 1945 yang terdiri dari 2 (dua) ayat menyatakan sebagai berikut : Hubungan wewenang antara pemerintah pusat dan pemerintahan daerah provinsi, kabupaten, dan kota, atau antara provinsi dan kabupaten dan kota, diatur dengan undang-undang dengan memperhatikan kekhususan dan keragaman daerah; Hubungan keuangan, pelayanan umum, pemanfaatan sumber daya alam dan sumber daya lainnya antara pemerintah pusat dan pemerintahan daerah diatur dan dilaksanakan secara adil dan selaras berdasarkan undang-undang.

Sedangkan ketentuan Pasal 18B UUDNRI 1945 yang terdiri dari 2 (dua) ayat menyatakan sebagai berikut : Negara mengakui dan menghormati satuan-satuan pemerintahan daerah yang bersifat khusus atau bersifat istimewa yang diatur dengan undang-undang; Negara mengakui dan menghormati kesatuan-kesatuan masyarakat hukum adat beserta hak-hak tradisionalnya sepanjang masih hidup dan sesuai dengan perkembangan masyarakat dan prinsip Negara Kesatuan Republik Indonesia, yang diatur dalam undang-undang.

Beranjak dengan membaca dan memahami politik hukum dalam Pasal 18 UUDNRI 1945, maka secara tersirat (tidak tegas) menyatakan bahwa Indonesia dalam pola hubungan antara Pemerintah Pusat dengan Pemerintah Daerah menganut konsep desentralisasi asimetris. Hal tersebut bermakna bahwa konsep Pemerintahan Daerah di Indonesia bukan hanya satu, dan negara mengakui hal tersebut. Dengan demikian, politik hukum (legal policy) tentang desentralisasi yang digariskan UUDNRI Tahun 1945 mengisyaratkan keniscayaan penerapan "desentralisasi asimetris" yang menekankan kekhususan, keistimewaan, keberagaman daerah, serta kesatuan-kesatuan masyarakat 
hukum adat dan hak-hak tradisional yang diatur lebih lanjut dengan undang-undang. ${ }^{2}$ Telaah lebih jauh, ada tiga konsep otonomi daerah yang diinginkan dalam Pasal 18 UUDNRI 1945, yaitu: otonomi daerah seluas-luasnya, otonomi daerah khusus, dan otonomi daerah istimewa.

Pembentuk peraturan perundang-undangan sebagai tindak lanjut dari Pasal 18 UUDNRI 1945 belum menyadari politik hukum dalam pasal tersebut yang mengamanatkan kebijakan desentralisasi asimetris. Istilah desentralisasi asimetris menjadi hal yang menarik karena memang istilah ini tidak begitu jamak digunakan dalam berbagai wacana dan kajian. Dimensi terminologinya menjelaskan jika desentralisasi asimetris dapat diartikan sebagai transfer kewenangan khusus yang hanya diberikan kepada daerah tertentu dalam rangka menjaga eksistensi daerah dalam NKRI. ${ }^{3}$ Bangsa Indonesia lebih umum mengenal istilah otonomi seluas-luasnya, otonomi khusus, dan otonomi istimewa. Padahal ketiga istilah itulah yang dikenal dengan desentralisasi asimetris.

Undang-Undang Nomor Undang-Undang Nomor 44 Tahun 1999 Tentang Penyelenggaraan Keistimewaan Daerah Istimewa Aceh, Undang Undang Nomor 21 Tahun 2001 juncto Undang-Undang Nomor 35 Tahun 2008 Tentang Otonomi Khusus Propinsi Papua, Undang-Undang Nomor 29 Tahun 2007 Tentang Pemerintahan Provinsi Daerah Khusus Ibukota Jakarta Sebagai Ibukota Negara Kesatuan Republik Indonesia, dan Undang-Undang Nomor 13 Tahun 2012 Tentang Keistimewaan Daerah Istimewa Yogyakarta; merupakan wujud pelaksanaan desentralisasi asimetris di Indonesia secara empiris.

Penerapan desentralisasi asimetris (asymmetric decentralization) bukanlah sekedar pelimpahan kewenangan biasa dalam bentuk transfer kewenangan khusus yang hanya diberikan kepada daerah-daerah tertentu saja. Secara empiris kebijakan desentralisasi asimetris tersebut merupakan bagian dari strategi yang komprehensif dari Pemerintah Pusat untuk menarik simpati dan merangkul kembali daerah-daerah separatis yang hendak memisahkan diri dari Negara Kesatuan Republik Indonesia. Kebijakan tersebut mencoba mengakomodasi berbagai tuntutan dan identitas lokal ke dalam sistem

\footnotetext{
${ }^{2}$ Gunawan A. Tauda, "Desain Desentralisasi Asimetris Dalam Sistem Ketatanegaraan Republik Indonesia", Administrative Law \& Governance Journal, Vol. 1, No. 2, Nopember 2018, hlm. 415.

3 Andhika Yudha Pratama, "Pelaksanaan Desentralisasi Asimetris Dalam Tata Kelola Pemerintahan Daerah Di Era Demokrasi”, Jurnal Pendidikan Pancasila dan Kewarganegaraan, Vol. 10, No. 1, Pebruari 2015, hlm. 8 .
} 
pemerintah lokal yang khas, namun tetap dalam koridor Negara Kesatuan Republik Indonesia.

Andhika Yudha Pratama mengemukakan bahwa pemberian desentralisasi atau otonomi yang berbeda-beda di Indonesia yang terjadi selama ini, dilakukan dengan dua cara, yaitu: ${ }^{4}$ Melalui cara soft (lembut), misalnya untuk Daerah Istimewa Yogyakarta dan DKI Jakarta; Melalui cara hard (keras), misalnya Daerah Istimewa Aceh, Papua, dan Papua Barat yang disebabkan karena adanya tekanan separatis dan konflik yang tinggi. Lebih lanjut Andhika Yudha Pratama mengatakan:. Ada beberapa hal yang patut digarisbawahi dari pemaknaan dari desentralisasi asimetris ini. Desentralisasi asimetris diberikan sebagai jalan tengah dari potensi negatif (konflik SARA, spartisme, kesenjangan sosial, masalah pemerataan pembangunan) yang berkembang di dalam sosio-kultural masyarakat setempat. Pola pelaksanaan pemerintahan lokal ini yang sedikit tidak mainstream, terbungkus dalam penggunaan istilah daerah khusus, otonomi khusus dan daerah istimewa, istilah tersebut yang jamak digunakan.

Desentralisasi asimetris lahir sebagai solusi atas fakta empiris bahwa pemberlakuan desentralisasi yang simetris di masing-masing daerah ternyata tidak dapat dilaksanakan secara merata di seluruh provinsi di Indonesia. Indonesia adalah negara majemuk (beragam) dengan kondisi geografi yang sangat luas, seperti yang dikemukakan oleh Jusuf Madubun, Haedar Akib, dan Jasruddin: ${ }^{6}$ The geographical condition of Indonesia as an archipelagic country, two-thirds of its territory is the Ocean that consists of coasts, seas, bays, and straits. The coast has $95181 \mathrm{~km}$ long with 5.8 million $\mathrm{km}^{2}$ water area. Indonesia has more than 17,000 islands with a diversity of ethnic, religious and cultural.

Kebijakan desentralisasi asimetris menjadi jalan yang solutif atau alternatif dari konsep desentralisasi simteris yang dinilai kurang berhasil memberikan rasa adil atau menumbukan kemandirian daerah, serta kesejahteraan bagi masyarakat daerah. Lebih lanjut Jusuf Madubun, Haedar Akib, dan Jasruddin mengatakan: "Asymmetric decentralization is a form of decentralization that was developed from the concept of decentralization itself, to distinguish it from the symmetrical decentralization that has been in force in various countries". 7 Mendasarkan pada uraian tersebut di atas, maka

4 Ibid.

5 Ibid.

6 Jusuf Madubun, Haedar Akib, dan Jasruddin, "The Prototype Model of Asymmetric Decentralization in Providing Public Services to the Island Areas", Mediterranean Journal of Social Sciences, Vol. 8, No.2, Maret 2017, hlm. 209.

7 Ibid, hlm. 211. 
tulisan ini mengambil judul: "Penegasan Kebijakan Desentralisasi Asimetris Dalam Rangka Menata Hubungan Pemerintah Pusat Dengan Pemerintah Daerah Di Indonesia”. Adapun titik tolak kajian dalam tulisan ini, antara lain: urgensi penegasan kebijakan desentralisasi asimetris dalam rangka menata pola hubungan pemerintah pusat dengan pemerintah daerah di Indonesia serta konstruksi dasar undang-undang pokok tentang kebijakan desentralisasi asimetris di Indonesia.

\section{B. Pembahasan}

\section{Urgensi Penegasan Politik Hukum Desentralisasi Asimetris Dalam Rangka Menata} Hubungan Pemerintah Pusat Dengan Pemerintah Daerah Di Indonesia

Politik hukum penyelenggaraan pemerintahan daerah diatur pada Bab VI Pasal 18, Pasal 18A dan Pasal 18B UUDNRI 1945. Pengaturan tersebut, merupakan ketentuan pasca amandemen UUD 1945, khususnya amandemen II yang ditetapkan pada tanggal 18 Agustus 2000. Amandemen UUD 1945 khususnya pada Pasal 18 telah membawa konsekuensi yang berbeda terhadap pelaksanaan dan penyelenggaraan pemerintahan di daerah saat ini.

Bagir Manan berpendapat terdapat tiga prinsip utama yang tertuang dalam politik hukum pemerintahan daerah berdasarkan pada Pasal 18 UUD 1945 (sebelum amandemen), yaitu: ${ }^{8}$ 1. Prinsip desentralisasi teritorial wilayah Negara Republik Indonesia akan dibagi-bagi dalam satuan-satuan pemerintahan yang tersusun dalam daerah besar dan kecil (grondgebied). Dengan demikian UUD 1945 tidak mengatur mengenai desentralisasi fungsional; 2. Perintah kepada pembentuk undang-undang (Presiden dan DPR) untuk mengatur desentralisasi teritorial tersebut dalam undangundang (undang-undang organik); 3. Perintah kepada pembentuk undang-undang dalam menyusun undang-undang tentang desentralisasi teritorial harus: (a) Memandang dan mengingati dasar permusyawaratan dalam sistem pemerintahan negara. (b)

Memandang dan mengingati hak-hak asal-usul dalam daerah-daerah yang bersifat istimewa.

Lebih lanjut Magir Manan sebagaimana dikutip oleh Aries Djaenuri, menyatakan bahwa: ${ }^{9}$ Prinsip pertama dan prinsip ketiga merupakan prasyarat yang tidak dapat disimpangi atau diabaikan begitu saja oleh pembuat undang-undang. Prinsip pertama

\footnotetext{
${ }^{8}$ Bagir Manan, 1994, Hubungan Antara Pusat Dan Daerah Menurut UUD 1945, Jakarta, Pustaka Sinar Harapan, hlm. 2019.

9 Aries Djaenuri, 2006, Hubungan Pusat dan Daerah, Jakarta, Penerbit Universitas Terbuka, hlm. 29.
} 
berisi perintah bahwa pembuat undang-undang dalam melaksanakan ketentuan Pasal 18 UUD 1945 hanya diijinkan mengatur mengenai desentralisasi teritorial dan pada prinsip ketiga bahwa materi atau substansi undang-undang sebagai pelaksanaan Pasal 18 UUD 1945 harus mencerminkan dasar-dasar permusyawaratan dalam sistem pemerintahan negara dan hak-hak asal-usul dari daerah-daerah bersifat istimewa.

Politik hukum pemerintahan daerah sebagaimana amanat Pasal 18, Pasal 18A, dan Pasal 18B UUDNRI 1945 mengalami perkembangan dibandingkan dengan Pasal 18 UUD 1945 (sebelum amandemen). Berdasarkan rumusan pemerintahan daerah sebagaimana tertuang Pasal 18, Pasal 18A dan Pasal 18B UUDNRI 1945, secara yuridis dapat digambarkan konstruksi besar bangunan otonomi daerah di Indonesia, terbagi menjadi tiga, yaitu: otonomi seluas-luasnya, otonomi istimewa dan otonomi khusus.

Lebih lanjut, mengenai hubungan antara Pemerintah Pusat dan Pemerintah Daerah, Pasal 18A (1) UUDNRI 1945 menyatakan bahwa: "Hubungan wewenang antara pemerintah pusat dan pemerintahan daerah provinsi, kabupaten dan kota, atau antara provinsi dan kabupaten dan kota, diatur dengan undang- undang dengan memperhatikan kekhususan dan keragaman daerah". Frasa kata "dengan memperhatikan kekhususan dan keragaman daerah" dalam Pasal 18A ayat (1) UUDNRI 1945 tersebut sebenarnya mengindikasikan bahwa konstitusi menghendaki adanya pengaturan yang berbeda bagi tiap-tiap daerah yang mempunyai corak khusus dan beragam. Hal tersebut semakin diperkuat dengan adanya Pasal 18B ayat (1) UUDNRI Tahun 1945 yang menyatakan bahwa: "Negara mengakui dan menghormati satuan-satuan pemerintahan daerah yang bersifat khusus atau bersifat istimewa yang diatur dengan undang-undang”. Mendasarkan pada uraian tersebut, maka secara filosofi politik hukum (legal policy) tentang desentralisasi yang digariskan UUDNRI 1945 mengamanatkan penerapan "desentralisasi asimetris" yang menekankan, menghargai, dan menghormati kekhususan, keistimewaan, keberagaman daerah, serta kesatuan-kesatuan masyarakat hukum adat dan hak-hak tradisional yang diatur lebih lanjut dengan undang-undang.

Pada tataran sejarah (historis), Indonesia sudah menjalankan kebijakan desentralisasi asimetris sejak diberlakukan Desentralisatie Wet 1903 pada zaman Hindia Belanda, yang meskipun pada saat itu cenderung sentralisasi, namun Pemerintah Hindia Belanda mengakui dan menghormati daerah-daerah istimewa dan otonom, yang pada saat itu dikelompokkan menjadi dua, yaitu: Zelfbesturende landschappen dan volkgemeenschappen sebagai satuan daerah yang memiliki pemerintahan dengan karakter 
yang khusus atau istimewa. Zelfbesturende landschappen dan volkgemeenschappen merupakan pemerintahan asli Indonesia. Zelfbesturende landschappen dan volkgemeenschappen bukan suatu susunan pemerintahan yang dibentuk atau dibuat berdasarkan peraturan perundang-undangan atau pemerintahan Hindia Belanda, melainkan pemerintahan yang diciptakan dan dijalankan oleh kaum "bumiputra". Pemerintahan zelfbesturende landschappen dan volkgemeenschappen sudah ada jauh sebelum masa Belanda datang ke bumi nusantara. Pada masa kemerdekaan zelfbesturende landschappen dikenal dengan istilah "swapraja". Swapraja merupakan persekutuan hukum teritorial Indonesia asli dengan sifat hukumnya sendiri. Volkgemeenschappen adalah daerah otonom yang dibiarkan mengatur dan mengurus urusan rumah tangganya sendiri, yang ditafsirkan sama dengan desa, nagari, marga, dusun, dan lain sebagainya.

Secara empiris (praktek saat ini), Indonesia telah memberlakukan kebijakan desentralisasi asimetris di Daerah Istimewa Aceh, Daerah Khusus Ibu Kota Jakarta, Daerah Istimewa Yogyakarta, Otonomi Khusus Papua, Otonomi Khusus Papua Barat, Kawasan Batam, dan daerah perbatasan Kalimantan Utara. Berbagai pertimbangan dalam menetapkan keistimewaan dan kekhususan daerah-daerah tersebut, antara lain: Alasan konflik di daerah dengan pusat dan menguatnya tuntutan separatisme; Pemberian status khusus kepada Daerah Khusus Ibukota Jakarta (DKI Jakarta) sebagai ibukota Negara Kesatuan Republik Indonesia; Alasan sejarah dan budaya yang khusus dari suatu daerah; Alasan daerah perbatasan teritorial dengan negara lain. Perbatasan perlu mendapatkan perlakuan khusus mengingat perannya sebagai batas teritorial dengan negara tetangga; Pusat pengembangan ekonomi.

Penegasan mengenai kebijakan desentralisasi asimetris perlu dilakukan, dengan pertimbangan: Pertama, Politik hukum Pasal 18, Pasal 18A, dan Pasal 18B UUDNRI 1945 memang mengamanatkan bahwa desentralisasi asimetris adalah pilihan yang tepat situasi Indonesia saat ini dalam pola hubungan pemerintah pusat dengan pemerintah daerah. Indonesia merupakan negara yang memiliki wilayah yang luas, jumlah penduduk yang sangat padat, penuh keberagaman, kekhususan, dan keistimewaan, sehingga tidak tepat apabila memberlakukan "desentralisasi simetris".

Kedua, Untuk menjamin kepastian hukum, bahwa tetap terjaganya politik hukum Pasal 18, Pasal 18A, dan Pasal 18B UUDNRI 1945 sampai pada tataran praktis. Hal ini karena, pembentuk undang-undang karena kewenangannya sering menafsirkan sendiri politik hukum yang terkandung dalam Pasal 18, Pasal 18A, dan Pasal 18B UUDNRI 
1945. Kondisi ini menyebabkan setiap ganti rezim yang berkuasa, maka pola desentralisasinya pun berubah-ubah. Hal ini dapat terlihat dari pemberlakuan tiga undang-undang yang berkaitan dengan pemerintah pasca amandemen Pasal 18 UUD 1945. Sejak berlakunya Pasal 18, Pasal 18A, dan Pasal 18B UUDNRI 1945, Indonesia telah menetapkan tiga undang-undang pemerintahan daerah (otonomi daerah), yaitu: Undang-Undang Nomor 22 Tahun 2019, Undang-Undang Nomor 32 Tahun 2004, dan Undang-Undang Nomor 23 Tahun 2014. Ketiga undang-undang tersebut memiliki payung hukum yang sama, yaitu bersumber pada Pasal 18, Pasal 18A, dan Pasal 18B UUDNRI 1945; namun semangat otonomi daerah dalam ketiga undang-undang tersebut berbeda. Ketiga undang-undang otonomi daerah tersebut pun belum ada yang mengatur mengenai desentralisasi asimetris. Kepastian tidak hanya mengenai desentralisasi asimetris, tetapi kepastian untuk tidak lagi sentralisasi. Negara Kesatuan Republik Indonesia dengan wilayah yang sangat luas, jumlah penduduk yang sangat banyak, dan beragam dalam etnis, bahasa, agama, dan kebudayaan; maka penyelenggaraan pemerintahan daerah dalam hal pola hubungan pemerintah pusat dan pemerintah daerah yang tepat adalah desentralisasi bukan sentralisasi, seperti yang permah terjadi pada masa Pemerintahan Orde Baru dan sebagian saat Pemerintah Orde Lama berkuasa.

\section{Konstruksi Dasar Undang-Undang Pokok Tentang Kebijakan Desentralisasi}

\section{Asimetris di Indonesia}

Penegasan kebijakan desentralisasi asimetris dapat dilakukan dengan membuat grand design desentralisasi asimetris terlebih dahulu yang nantinya tertuang dalam produk hukum berbentuk undang-undang. Undang-undang tersebut akan menjadi undang-undang pokok atau undang-undang induk yang membawahi tiga kelompok undang-undang yang terlah ada sebagai pelaksanaan otonomi daerah, yaitu: 1). Pelaksanaan otonomi daerah seluas-luasnya, sebagaimana diatur dalam Undang-Undang Nomor 23 Tahun 2014 Tentang Pemerintahan Daerah; 2). Pelaksanaan dari otonomi khusus, antara lain: Undang-Undang Nomor 29 Tahun 2007 Tentang Pemerintahan Provinsi Daerah Khusus Ibukota Jakarta Sebagai Ibukota Negara Kesatuan Republik Indonesia dan Undang Undang Nomor 21 Tahun 2001 juncto Undang-Undang Nomor 35 Tahun 2008 Tentang Otonomi Khusus Propinsi Papua. 3). Pelaksanaan dari otonomi daerah istimewa, antara lain: Undang-Undang Nomor Undang-Undang Nomor 44 Tahun 1999 Tentang Penyelenggaraan Keistimewaan Daerah Istimewa Aceh dan UndangUndang Nomor 13 Tahun 2012 Tentang Keistimewaan Daerah Istimewa Yogyakarta. 


\section{Gambar 1 Kedudukan Rancangan Undang-Undang Pokok Desentralisasi Asimetris Dalam Hukum Pemerintahan Daerah di Indonesia}

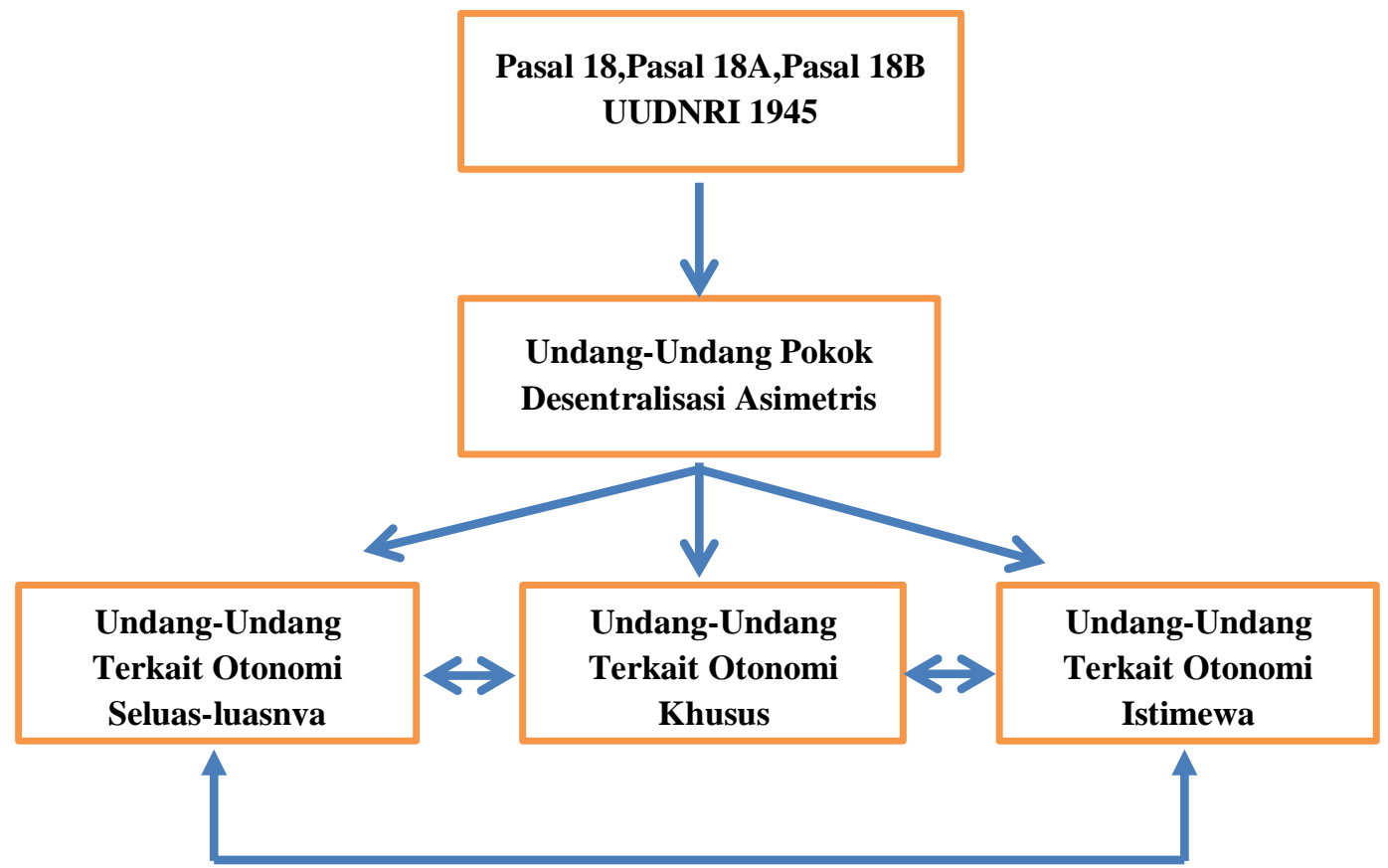

Diolah: Dari berbagai teori.

Keberadaan undang-undang pokok desentralisasi asimetris tersebut akan menjadi payung hukum bagi pemerintah daerah di dalam menetapkan pola hubungannya dengan pemerintah pusat. Beberapa prinsip yang dapat diajukan dalam menyusun konstruksi bangunan hukum terkait desentralisasi asimetris tersebut, antara lain: 1). Pelaksanaan desentralisasi asimetris dalam bingkai Negara Kesatuan Republik Indonesia. Konsep desentralisasi tidak mengarah untuk mewujudkan daerah federal atau "there is no state in the state". Penegasan ini penting untuk tetap menjaga keutuhan Negara Kesatuan Republik Indonesia yang berdasarkan Pancasila, UUDNRI 1945, dan Bhineka Tunggal Ika. 2). Konstruksi berikutnya adalah menjadikan undang-undang ini sebagai undangundang pokok dalam penyelenggaraan pemerintahan daerah di Indonesia. Undangundang ini menjadi grand design kebijakan desentralisasi asimetris, yang nantinya akan membawahi undang-undang yang berkaitan dengan otonomi seluas-luasnya, otonomi khusus, dan otonomi istimewa. Ketiga undang-undang otonomi tersebut akan menjadi lex specialis dari undang-undang desentralisasi asimetris. 3). Pembentukan badan otonomi daerah yang memiliki kewenangan untuk memberikan rekomendasi bagi pemerintah pusat untuk menetapkan pola hubungan antara pemerintah pusat dengan pemerintah 
daerah. Badan atau lembaga ini juga diberi kewenangan untuk mengevaluasi pelaksanaan desentralisasi asimetris dari masing-masing pemerintah daerah. Badan atau lembaga ini setingkat menteri berada di presiden langsung. Badan ini juga diberi kewenangan untuk menentukan indikator atau kriteria mengenai daerah dengan otonomi seluas-luasnya, otonomi daerah khusus dan otonomi daerah istimewa. 4). Terdapat peluang bagi Pemerintah daerah, baik pemerintah daerah provinsi maupun pemerintah daerah kabupaten/kota untuk mengajukan sendiri (proposal) mengenai pola hubungannya dengan pemerintah pusat, sesuai dengan kondisi daerah tersebut dan diselaraskan dengan indikator kemandirian, kekhususan atau keistimewaannya. Mendasarkan pada hal tersebut, maka tidak perlu menetapkan titik berat otonomi daerah. Titik berat otonomi dapat ditentukan sendiri dengan indikator yang telah ditetapkan, serta titik beratnya bersifat dinamis, sehingga dapat berubah-ubah setiap saat sesuai kemampuan dan kondisi daerah tersebut. Kedudukan undang-undang pokok desentralisasi asimetris terhadap undang-undang otonomi daerah lainnya, dapat digambarkan sebagai berikut:

\section{Simpulan}

Berdasarkan uraian pembahasan pada bab sebelumnya, maka dapat ditarik beberapa kesimpulan, antara lain: Pertama, Urgensi penegasan politik hukum desentralisasi asimetris adalah untuk menjamin kepastian dalam penyelenggaraan pemerintahan daerah di Indonesia menganut konsep "desentralisasi" bukan "sentralisasi, dan desentralisasi yang dianut adalah "asimetris" bukan "simetris". Kepastian tersebut diperlukan agar setiap pemerintahan yang berkuasa tidak menafsirkan sendiri politik hukum penyelenggaraan pemerintahan daerah sesuai kepentingan rezim tersebut. Politik hukum pemerintahan daerah sebagaimana amanat Pasal 18, Pasal 18A, dan Pasal 18B UUDNRI 1945 harus dikawal supaya on the track.

Kedua, Pembentukan undang-undang pokok tentang desentralisasi asimetris merupakan salah satu sarana hukum untuk mewujudkan kepastian atau keberlangsungan desentralisasi asimetris di Indonesia. Prinsip-prinsip dalam undang-undang pokok tentang desentralisasi asimetris sebagai kontruksi awal dari ketentuan pokok tersebut, antara lain: Pelaksanaan desentralisasi asimetris dalam bingkai Negara Kesatuan Republik Indonesia. Undang-undang tersebut sebagai undang-undang pokok dalam penyelenggaraan pemerintahan daerah di Indonesia, yang nantinya akan membawahi undang-undang yang berkaitan dengan otonomi seluas-luasnya, otonomi khusus, dan otonomi istimewa; Pembentukan badan otonomi daerah; Pemerintah daerah memilih pola 
hubungannya dengan pemerintah pusat dari ketiga otonomi yang sudah ada selama ini, otonomi seluas-luasnya, otonomi khusus, dan otonomi istimewa, serta titik berat otonomi bersifat dinamis.

Terkait permasalahan yang telah diuraikan pada bab sebelumnya, maka saran atau rekomendasi yang dapat disampaikan, yaitu: pembentukan undang-undang kebijakan desentralisasi asimetris dengan pokok-pokok pikiran sebagaimana yang telah diuraikan pada bab sebelumnya, dengan terlebih dahulu membuat kajian akademis atau naskah akademis mengenai desentralisasi asimetris.

\section{Daftar Pustaka}

Arya Utama I Made, "Pembangunan Berkelanjutan Dalam Kerangka Otonomi Daerah", Jurnal Konstitusi, Vol. I No. 1, 2008.

Asshiddiqie Jimly, 2012, Hukum Tata Negara dan Pilar-Pilar Demokrasi, Sinar Grafika, Jakarta.

Djaenuri Aries, 2006, Hubungan Pusat dan Daerah, Jakarta, Penerbit Universitas Terbuka.

Madubun Jusuf, Akib Haedar, dan Jasruddin, "The Prototype Model of Asymmetric Decentralization in Providing Public Services to the Island Areas", Mediterranean Journal of Social Sciences, Vol. 8, No.2, Maret 2017.

Mahfud MD Moh., 2011, Kedudukan Komisi-Komisi Negara dalam Sistem Ketatanegaraan Kita, AlFaqih-Supra Note 4, Jakarta.

Manan Bagir, 1994, Hubungan Antara Pusat Dan Daerah Menurut UUD 1945, Jakarta, Pustaka Sinar Harapan.

Marbun, S.F., 2014, Asas-Asas Umum Pemerintahan Yang Layak, FH UII Press, Yogyakarta.

Pratama Andhika Yudha, "Pelaksanaan Desentralisasi Asimetris Dalam Tata Kelola Pemerintahan Daerah Di Era Demokrasi”, Jurnal Pendidikan Pancasila dan Kewarganegaraan, Vol. 10, No. 1, Pebruari 2015.

Rasyid Ryaas, 1998, Desentralisasi dalam Menunjang Pembangunan Daerah dalam Pembangunan Administrasi di Indonesia, Pustaka LP3ES, Jakarta.

Tauda Gunawan A., "Desain Desentralisasi Asimetris Dalam Sistem Ketatanegaraan Republik Indonesia", Administrative Law \& Governance Journal, Vol. 1, No. 2, Nopember 2018.

Undang Undang Nomor 21 Tahun 2001 Tentang Otonomi Khusus Propinsi Papua.

Undang-Undang Dasar Negara Republik Indonesia 1945.

Undang-Undang Nomor 13 Tahun 2012 Tentang Keistimewaan Daerah Istimewa Yogyakarta.

Undang-Undang Nomor 22 Tahun 1999 Tentang Pemerintahan Daerah.

Undang-Undang Nomor 23 Tahun 2014 Tentang Pemerintahan Daerah.

Undang-Undang Nomor 29 Tahun 2007 Tentang Pemerintahan Provinsi Daerah Khusus Ibukota Jakarta Sebagai Ibukota Negara Kesatuan Republik Indonesia.

Undang-Undang Nomor 32 Tahun 2004 Tentang Pemerintahan Daerah.

Undang-Undang Nomor 35 Tahun 2008 Tentang Perubahan Undang Undang Nomor 21 Tahun 2001 Otonomi Khusus Propinsi Papua.

Undang-Undang Nomor Undang-Undang Nomor 44 Tahun 1999 Tentang Penyelenggaraan Keistimewaan Daerah Istimewa Aceh. 
Wibawa Kadek Cahya Susila, "Urgensi Keterbukaan Informasi Dalam Pelayanan Publik Sebagai Upaya Mewujudkan Tata Kelola Pemerintahan Yang Baik", Administrative Law \& Governance Journal, Vol. 2, No. 2, Juni 2019. 